\title{
The influence of supply chain management on competitive advantage and company performance
}

\author{
Maun Jamaludin ${ }^{\mathrm{a}^{*}}$
}

${ }^{a}$ Department of Business Administration, Pasundan University, Bandung, Indonesia

\begin{tabular}{l}
\hline C H R O N I C L E \\
\hline Article history: \\
Received November 25, 2020 \\
Received in revised format \\
January, 29, 2021 \\
Accepted April 202021 \\
Available online \\
April 202021 \\
\hline Keywords: \\
Supply chain management \\
Competitive advantage \\
Company performance \\
Small and Medium Enterprises \\
Structural Equation Modeling \\
(SEM)
\end{tabular}

\section{A B S T R A C T}

\begin{abstract}
At present, the condition of competition in a network is very tight due to rapid technological changes, economic and political stability in Indonesia which is experiencing uncertainty, and the large number of foreign investors entering, as well as new competitors. Companies themselves are required to always innovate in today's increasingly modern era. This competition must be able to create a good network in order to create competitive advantage and company performance in the formation of good Supply Chain Management. This study aims to determine the effect of supply chain management on competitive advantage and company performance. This study will examine supply chain management on competitive advantage and company performance in Small and Medium Enterprises (SMEs) in Bandung City, West Java. In this study, there are several differences from previous research, namely the indicators that will be used in this study. Namely, the measured supply chain management variables are indicators of technology use, supply chain speed, customer satisfaction, supply chain integration and inventory management. The variables of competitive advantage that are measured are the indicators of Price, Quality, and Time to market, and sales growth. Meanwhile, the measured company performance variables are indicators of financial performance and operational performance. The analytical method used in testing the hypothesis is to use Structural Equation Modeling (SEM) with the help of AMOS software version 20. Respondents in this study were 150 respondents in Small and Medium Enterprises (SMEs) in Bandung, West Java. The results of this study indicate that supply chain management has a positive and significant effect on the company's competitive advantage. Competitive advantage has a positive and significant effect on company performance. Supply chain management has a positive and significant effect on company performance. Supply chain management has a positive and significant effect on company performance through competitive advantage.
\end{abstract}

\section{Introduction}

We cannot avoid competition in the business world, therefore if you want to enter the business world, prepare yourself to face other business competitors. Currently, competition in the business world is very tight, so we must face it in a healthy way and in accordance with existing regulations. The existence of competitors or competitors in a business is normal. Business competition is one of the major risks that business people must face. Competition is something that must be faced by a company. Competitive advantage is a part of the success or failure of a company (Indrajit \& Djokopranoto, 2002). One of the keys to the success of a company is its ability to have and maintain one or more competitive advantages that can be achieved through various means. One way is through logistics management and Supply Chain management (Jamaludin et al., 2020; Jamaludin et al., 2021). According to Kuncoro (2006), competitive advantage is a key concept of strategic management, that is, a company is said to have a competitive advantage when the company has something that competitors do not have, does something better than other companies, or able to do something that no other company has been able to do. Thus, competitive advantage is an important requirement in achieving long-term success and company survival.

* Corresponding author

E-mail address: maunjamaludin.unpas@gmail.com (M. Jamaludin)

C 2021 by the authors; licensee Growing Science.

doi: $10.5267 /$ j.uscm.2021.4.009 
Competitive advantage refers to the company's ability to create unique value that competitors do not have and cannot imitate. Day and Wensley (1988) states that competitive advantage is a form of strategy to help the survival of the company. Competitive advantage is also a means to achieve the ultimate goal of the company, namely to improve company performance. Supply Chain Management is a means of optimizing company activities in company operations to minimize costs and achieve customer satisfaction which is realized by creating good relationships with suppliers, good production and relationships with good customers (Jamaludin et al., 2020). Failure in company operations when producing products/services or in any level can cause failure costs to increase which will then cause the company's profitability to decrease and cause purchasing power to decrease as well (Jamaludin et al., 2020). Supply Chain Management can minimize costs incurred by the company and can increase the value of product quality in the eyes of customers so that the company's profitability will increase. This condition is expected to improve company performance (Wulandari et al., 2017).

There are many factors that can increase the company's production, such as increasing the quality of human resources, increasing the quality of raw materials, and reducing the production failure rate at the company. The quality of raw materials is closely related to suppliers. The interaction of companies with suppliers to get raw materials used for production is one of the activities that are closely related to the supply chain or Supply Chain Management. Management of company operational activities in order to obtain raw goods, processing raw goods into in-process goods and/or finished goods, then sending these goods to consumers through the distribution system are activities that are integrated into Supply Chain Management (Ilmiyati \& Munawaroh, 2016). This study will examine the relationship between Supply Chain Management and company performance. The effect of supply chain management on company performance has been tested empirically in research (Li et al., 2006; Ilmiyati \& Munawaroh, 2016; Alimohamadian \& Abdi, 2014). In this study, the competitive advantage variable will be added as an intervening variable in testing the influence of Supply Chain Management on company performance with the assumption that competitive advantage is a stepping stone for the company to achieve good performance. This is supported by the opinion of Day \& Wensley (1988) which states that competitive advantage is a form of strategy to help companies maintain their survival. Excellence in competition is a means to achieve the ultimate goal of the company, namely improving company performance. Previous research has shown that Supply Chain Management has an effect on competitive advantage (Li et al., 2006; Henriksson \& Nyberg, 2005; Thakkar et al., 2008; Wu et al., 2014). Referring to previous research, this study will examine the role of competitive advantage variables as full mediation or partial mediation in examining the effect of Supply Chain Management on company performance.

\section{Theoretical Review}

\subsection{Supply Chain Management Concepts}

Supply Chain Management is a set of approaches that are applied to achieve efficient integration of suppliers, manufacturers, warehouses, and storage, so that goods can be produced and distributed in the right quantity, in the right location, the right time to minimize costs and provide services that satisfy the needs of the end customer (Larson, 2001; Simchi-Levi et al., 2008). Supply Chain Management is a process of continuous integration of customer needs, internal processes, and supplier performance (Tan, 2001). In a simple supply chain, there are several main components of the supply chain consisting of suppliers, manufacturers, warehouses and distribution centers, wholesalers, retailers with the ultimate goal of being meet the demands of end consumers (Simchi-Levi et al., 2008). In the implementation of supply chain management, the supply chain plays an important role in improving company performance (Jamaludin et al., 2021). The implementation of supply chain management is a series of activities by the organization which aim to increase the efficiency of supply chain management. According to Banerjee \& Mishra (2017) the practice of supply chain management is divided into three main concepts, namely: (1) relationships with customers; (2) relationships with suppliers; (3) factors in the company (internal factors). In line with Banerjee \& Mishra (2017) research, research from Lee (2015) states that supply chain management practices are divided into three, namely: (1) customer linkage; (2) relationships with suppliers (supplier linkage), and relationships within the company (internal linkage). The supply chain includes the entire interaction between suppliers, manufacturing companies, distributors and consumers. This interaction is also related to transportation, scheduling information, credit and cash transfers, as well as the transfer of raw materials between the parties involved (Harrison \& Van Hoek, 2008).

\subsection{Competitive Advantage}

According to Porter (1985) Competitive advantage is the ability obtained through the characteristics and resources of a company to have a higher performance than other companies in the same industry or market. Competitive advantage is the advantage over competitors obtained by offering greater consumer value, either at a lower price or by providing greater profits and services that provide a higher price. The competitive advantage can be obtained if the company has the ability to better present each of its business operational processes in producing goods and services with high quality and competitive prices. So that the resulting product is able to compete both in terms of quality, price, product delivery, and flexibility compared to its competitors in the market (Heizer \& Render, 2008). Competitive advantage can be applied if a company can achieve strategic advantage, tactical advantage and operational excellence (Fink \& Disterer, 2011). In order to achieve the goals that are superior to competitors, the company must formulate a strategy that is suitable for both internal and external conditions of the company which is then implemented in competition and creates excellence in its daily processes. 
In achieving competitive advantage, according to Porter (1985), companies need to pay attention to the five competitive forces. First: the intensity of competition among existing competitors, factors that directly influence competition are industry growth, product differences, number and diversity of competitors, fixed costs, and constraints to exit the industry. Second: the bargaining power of the customer, the factors that affect the purchasing power are the number of buyers, the switching costs of the buyer, the ability of the buyer to reintegrate, the impact of the product from the business unit on the total cost of the buyer, the impact of the business unit's product on the quality/performance of the buyer's product and the significance of the volume of the business unit for the buyer. Third: bargaining power of suppliers, factors that influence supplier power are the number of suppliers, the ability of suppliers to carry out future integration, the presence of substitute inputs, and the importance of business unit volume for suppliers. Fourth: the threat of substituted goods, the factors that influence the threat of substituted goods are the relative price/performance of the substituted goods, the buyer 's switching costs, and the buyers' tendency to use the substituted goods. Fifth: the threat of new entrants to the industry, factors that affect the barriers to entry into the industry are capital requirements, access to distribution channels, economies of scale, product differentiation, technological complexity of products or processes, expected retaliation from companies already exists, and government policies. Porter (1985) then continues that there are three observations made in connection with the industry analysis, namely the stronger the five forces, the lower the probability of profitability of the industry; depending on the five forces, the key strategic problems faced by the business unit will differ from one industry to another; and understanding the nature of each strength helps companies formulate effective strategies.

From the analysis of the five competitive forces above, it is a starting point for developing competitive advantage because it helps identify opportunities and threats in the external environment. With this understanding, (Porter, 1985) claims that business units have generic ways of responding to opportunities in the external environment and developing sustainable competitive advantage in low cost and product differentiation. The low cost strategy focuses on how the company can operate to produce a product or service at a relatively lower cost compared to its competitors. Product differentiation refers to a company's ability to offer superior and unique products or services compared to products or services produced by competitors.

\subsection{Company Performance}

Company performance is a measure of the success of a company which is measured over a specified time period. This result can be said to be a value of each activity that has been compiled and implemented to be able to identify whether the strategy that has been made and the implementation of the strategy is correct or vice versa (Kushwaha, 2011). Fink \& Disterer (2011) states that competitive advantage is a form of strategy to help the survival of the company. Excellence in competition is a means to achieve the ultimate goal of the company, namely improving company performance. The performance targets set by the company will motivate personnel to achieve these targets. The target set will be a measure of the success or failure of the company and each member of the company in carrying out operational activities. Good performance will have an impact on the company's survival. To achieve good performance, it is necessary to have a performance appraisal. Performance appraisal is also used to suppress and prevent inappropriate behavior from occurring and to design and enforce behavior that should be desired, through timely feedback on performance results and rewards, both intrinsic and extrinsic in nature. Green et al., (2008); Lin \& Ho (2007) stated that company performance can be assessed from the company's financial performance and non-financial performance. de Souza Miguel \& Brito (2011) state that company performance can be measured using three indicators, namely financial performance, operational performance, and market-based performance. Financial performance is generally measured by measurement based on accounting data, such as the measurement of profitability which includes return on assets, return on investment, return on sales, and return on capital. Performance measurement from a non-financial perspective has received more attention for years as the number of companies has grown. Obeidat (2016) states that the main advantage of measuring operational performance compared to financial performance is when the available information is related to opportunities that already exist, but have not been financially realized. Operational performance can generally be measured using measurements such as market share, new product launches, product/service quality, marketing effectiveness, and customer satisfaction (de Souza Miguel \& Brito, 2011). Overall market-based performance will be affected when the market finds out information about the company's operations that is not included in the company's performance results. The rate of return to shareholders, market value added and annual profits can be used to measure market-based performance (de Souza Miguel \& Brito, 2011).

\subsection{Structural Issues in the Development of Small and Medium Enterprises}

The issue of small and medium enterprises (SMEs) has become a major focus of literature. Many researchers have tried to classify SMEs as a business category. Some researchers classify SMEs based on business size, venture capital, worker skills, and level of turning points. Others measure SMEs based on their formal legal status and production methods (Abor \& Quartey, 2010). The concept of Small and Medium Enterprises (SMEs) in Indonesia has developed over time and has various meanings (Abor \& Quartey, 2010). The latest concept that accommodates all aspects of SMEs is found in Law Number 20 of 2008 (Law No. 20 of 2008), which states that Small and Medium Enterprises are productive economic enterprises that are independent, carried out by individuals, or business entities that are not a subsidiary, or not a branch of a company that is owned, controlled, or is a direct or indirect part of a medium or large business that meets the criteria for a small business as referred to in the law (Law No. 20 of 2008 Article 1 paragraphs 1 and 2). 
The criteria for small and medium enterprises according to Law number 20 of 2008 are as follows. First, having a net worth of more than IDR 50,000,000.00 (fifty million rupiahs) up to a maximum of IDR 500,000,000.00 (five hundred million rupiahs), excluding land and buildings for business premises. Second, having annual sales revenue of more than IDR $300,000,000.00$ (three hundred million rupiah) up to a maximum of Rp. 2,500,000,000.00 (two billion rupiah). SMEs have a history in the economy in Indonesia, especially in the absorption of labor and main generators as a source of income for households. As a driver of the country's economic development. Tambunan (2008) states that SMEs in Indonesia have five characteristics. First, the majority of SMEs in Indonesia is owned by indigenous people and absorbs a lot of workforce. Second, SMEs are very common in rural areas with an agricultural business base. Third, SMEs absorb labor from various backgrounds, such as low education and young people. Fourth, SMEs in Indonesia obtain financial resources through personal savings. Fifth, SMEs produce simple goods, serve the domestic market, and target lowincome consumers.

The development of SMEs in Indonesia has experienced many lessons since the economic crisis in 1998 in Indonesia. The revival of SMEs in Indonesia was the result of the 1998 financial crisis. During the financial crisis in 1998, SMEs were the last secure social business network and during that time and the unemployment rate in Indonesia increased rapidly. More than 12 million Indonesians have lost their jobs or about 11 percent of Indonesia's human resources (Agus et al., 2015).

In particular, SMEs in Indonesia account for $90 \%$ of all enterprises, and they are the largest source of employment and livelihoods for more than $90 \%$ of the working force in Indonesia, especially women and young people. SMEs with the smallest units such as micro-industries are widely spread in rural areas and are the beginning of development from rural areas through business (Tambunan, 2008). Data from the Ministry of Cooperatives \& SMEs in Indonesia shows that agriculture is the main sector of SMEs. The agricultural sector contributes about $86 \%$ to $87 \%$ of the total output of the SME sector in Indonesia. The second important sector is trade, hotels and restaurants with a share of between $74 \%$ and $76 \%$, followed by the financial services, leasing and services sector around $46 \%$ to $47 \%$, and the lowest in the transportation and communications sector with $23.47 \%$. In the manufacturing industry, SMEs in Indonesia are involved, both in simple manufacturing industries such as timber products, furniture, textiles, garments, shoes, and the food and beverage industry (Tambunan, 2008).

\section{Theoretical Framework and Hypothesis Formulation}

\subsection{The Effect of Supply Chain Management on Company Performance}

Supply Chain Management is a means of optimizing company activities in company operations to minimize costs and achieve customer satisfaction which is realized by creating good relationships with suppliers, good production and relationships with good customers. Failure in the company's operations when producing products/services or at any level can cause the cost of failure to increase which will then cause the company's profitability to decrease and cause purchasing power to decrease as well. Supply Chain Management can minimize costs incurred by the company and increase the value of product quality in the eyes of customers so that the company's profitability will increase. This condition is expected to improve company performance. Supply Chain Management has three objectives, namely cost reduction, capital reduction, and service improvement (Siagian, 2005). Of the three goals, the goal of cost reduction means that by implementing Supply Chain Management, companies can minimize logistics costs that occur, for example by choosing transportation tools/models, distribution methods or systems, warehousing, standards, and services that minimize costs. Likewise with the aim of capital reduction, the application of Supply Chain Management is expected to improve company performance by increasing the rate of return on capital. On the operational side of the company, Supply Chain Management will help companies to produce and distribute goods in the right quantity, in the right location, and in the right time. From this statement, it can be concluded that Supply Chain Management will be able to improve the company's operational performance. Then, the third goal of implementing Supply Chain Management as stated by Siagian (2005), namely the goal of service improvement, it is hoped that with Supply Chain Management, companies can make continuous service improvements so that customer satisfaction and loyalty can be maintained. From this description, it can be concluded that Supply Chain Management has an effect on company performance. This is supported by previous research (e.g. Li et al., 2006; de Souza Miguel \& Brito, 2011, Rahmasari, 2011; Henriksson \& Nyberg, 2005). From the description above, the following hypothesis is formulated:

\section{H1: Supply Chain Management has a positive effect on company performance.}

\subsection{Effect of Supply Chain Management on Competitive Advantage}

Competitive advantage leads to the company's ability to create unique values that competitors do not have and cannot imitate (Li et al., 2006). Competitive advantage at this time is not only determined by the ability of an industry to create multiple outputs per time but also regarding quality, distribution and after sales service. Productivity is important, but that alone is not sufficient as a provision to compete in the market. Customers are starting to be able to differentiate products based on their quality. It is even realized that the quality of the product is highly dependent on the production process, humans as producers, and the systems used as a whole. Quality control is no longer sufficient only to do with the product inspection model, but it is more fundamental by looking at the process. Even industrial people are starting to realize that product quality cannot be separated from the quality of raw materials sent by suppliers (Ubud, 2013). Supply Chain Management includes company activities in obtaining quality raw materials, good relationships with suppliers, effective and efficient production 
activities, good logistics systems, and satisfying customer service. The implementation of a good supply chain management can increase the selling value of the product and the value of the company in the eyes of consumers both in terms of product quality, the right distribution system, and satisfying service. From this description, it can be concluded that Supply Chain Management has an effect on the company's competitive advantage. This is supported by the results of research conducted by Li et al., (2006); Rahmasari (2011); Koh et al., (2007); Bratić (2011); Henriksson \& Nyberg (2005). Based on the description above, the following hypothesis is proposed:

\section{$\mathbf{H}_{2}$ : Supply Chain Management has a positive effect on competitive advantage.}

\subsection{The Effect of Competitive Advantage on Company Performance}

Company performance is a measure of the success of a company which is measured over a specified period of time. This result can be said to be a value of every activity that has been compiled and implemented to be able to identify whether the strategy that has been made and the implementation of the strategy is correct or vice versa (Prakosa \& Imam, 2005). According to Li et al., (2006) competitive advantage can be realized by focusing on price, quality, delivery dependability, product innovation, and time to market. Companies that focus on this will be superior to other companies. The company's superiority compared to competitors can attract many consumers, which in turn will increase the company's sales level and market share. Thus, the company's financial and non-financial performance will increase. Ubud (2013) states that competitive advantage is a form of strategy to help the survival of the company. Excellence in competition is a means to achieve the ultimate goal of the company, namely improving company performance. The results of other studies also support the opinion of Ubud (2013), such as Turban et al., (2013) and Rahmasari (2011). From this description, a hypothesis is formulated about the effect of company superiority on company performance as follows:

\section{$\mathbf{H}_{3}$ : Competitive advantage has a positive effect on company performance.}

\subsection{Effect of Supply Chain Management on Company Performance through Competitive Advantage}

Supply Chain Management is a set of approaches adopted by companies so that goods can be produced and distributed in the right amount, right location, and right time with good quality to minimize costs and provide services that satisfy consumers. Failure in the company's operations when producing products/services or at any level can cause the cost of failure to increase which will then cause the company's profitability to decrease and cause purchasing power to decrease as well. From this explanation, it can be concluded that Supply Chain Management can minimize costs incurred by the company and increase the value of product quality in the eyes of customers. The company's performance can be improved by the company's competitive advantage. With the fulfillment of company excellence indicators such as price, quality, delivery dependability, product innovation, and time to market, the company's sales level will increase. In addition, customer satisfaction and loyalty will also increase, which in turn will have an impact on improving company performance, both financial and non-financial. Customer satisfaction, quality of raw materials from suppliers, and distribution of products with the right time seem to be the key to competitive advantage in Supply Chain Management. From the description above, it can be seen that Supply Chain Management will affect company performance through the company's competitive advantage.

\section{$\mathbf{H}_{4}$ : Supply Chain Management has a positive effect on company performance through competitive advantage}

\section{Research Methods}

\subsection{Population and Sample}

Sampling in this study used the random sampling method, which is a sampling technique that takes samples randomly from previously determined populations. Considering that the population in Small and Medium Enterprises in Bandung City is very large and the time and costs of the researchers are limited, the number of samples in this research is 150 Small and Medium Enterprises throughout the city of Bandung.

\subsection{Variable Measurement}

In this study, researchers used indicators to be used, namely supply chain management variables measured from several indicators, namely technology use, supply chain speed, customer satisfaction, supply chain integration, inventory management. Competitive advantage variables measured are indicators of price, quality, time to market, and sales growth, while the variables measured company performance are indicators of financial performance and operational performance. All variables were measured by a questionnaire using a 5 Likert scale.

\subsection{Data Analysis}

The data analysis used in this research is Structural Equation Modeling (SEM) with the help of AMOS 20 software. The reason for using Structural Equation Modeling (SEM) an analysis tool is because this model can solve a multilevel hypothesis model simultaneously which cannot be solved by linear regression equations. In addition, SEM analysis, which is an extension and combination of several multivariate statistics, is suitable for management research, where social research is multidimensional and seems complicated. 


\section{Result \& Discussion}

To measure the validity of a questionnaire in this study, the validity test was carried out on each variable studied. The questionnaire is considered valid if the questions on the questionnaire are able to reveal something that will be measured by the questionnaire Imam (2013). The results of the calculation of the validity test can be seen in Table 1 below:

Table 1

Validity Test Results

\begin{tabular}{llll}
\hline Variable & Indicator & R Count & Validity \\
\hline Supply Chain Management & • Use of Technology (PT) & 0.546 & Valid \\
& • Supply Chain Speed (KRP) & 0.498 & Valid \\
& • Supply Chain Integration (IRP) & 0.589 & Valid \\
& • Inventory Management (MP) & 0.546 & Valid \\
Competitive Advantage & - Price (HRG) & 0.585 & Valid \\
& - Quality (KUA) & 0.624 & Valid \\
& - Time to Market (TTM) & 0.561 & Valid \\
Company performance & - Sales Growth (PP) & 0.611 & Valid \\
& • Financial Performance (KK) & 0.613 & Valid \\
\hline
\end{tabular}

Table 1 shows that all the indicators used to measure the variables in this study have a Corrected Item-Total Correlation value of more than or equal to 0.3 which indicates that all variables are declared valid. Testing this level of reliability using SPSS version 17.0 software which provides facilities for reliability with the Cronbach alpha $(\alpha)$ statistical test. An instrument is declared reliable if it has a Cronbach's Alpha coefficient $>0.6$ Imam (2013). The results of reliability testing can be shown in table 1 below:

Table 2

Reliability Testing Results

\begin{tabular}{llll}
\hline Variable & Alpha Cronbach & Critical Value & Result \\
\hline Company Performance & 0.760 & 0.6 & Reliable \\
Supply Chain Management & 0.749 & 0.6 & Reliable \\
Competitive Advantage & 0.787 & 0.6 & Reliable \\
\hline
\end{tabular}

Based on the summary of the reliability test results as summarized in Table 2 above, it can be seen that the Cronbach Alpha coefficient value of all variables is greater than 0.6 , so all the questions in the research variables are reliable, and all the questions in this study can be used to further research.

Table 3

Measurement Model - Goodness of fit

\begin{tabular}{|c|c|c|c|}
\hline Goodness of fit & Cut - off Value & Model Results & Information \\
\hline$\chi^{2}-$ Chi Square & It is expected that the value is small. With $\mathrm{DF}=32$ the table value $=56.9$ & 62,318 & \\
\hline Probability & $\geq 0,05$ & 0,001 & Not Fit \\
\hline $\mathrm{Cmin} / \mathrm{DF}$ & $\leq 2$ & 1,947 & Good Fit \\
\hline GFI & $\geq 0,90$ & 0,925 & Good Fit \\
\hline RMSEA & $\leq 0,080$ & 0,080 & Good Fit \\
\hline AGFI & $\geq 0,90$ & 0,871 & Not Fit \\
\hline TLI & $\geq 0,90$ & 0,921 & Good Fit \\
\hline CFI & $\geq 0,90$ & 0,944 & Good Fit \\
\hline
\end{tabular}

The value of $\chi^{2}$ - Chi Square with a significance level of $0.142>0.05$ or the calculated Chi square of $42.529<$ Chi square table 56.9. This shows that Ho, which states that there is no difference between the sample covariance matrix and the estimated population covariance matrix, is acceptable. This means that the covariance matrix of the sample with the covariance matrix of the estimated population is the same. Based on the analysis of goodnes of fit - GFI reflects the level of suitability of the overall model. GFI's recommended acceptance rate $>0.90$. The results show that the GFI value is $0.925>$ 0.9 , so that the model has a good fit. Adjusted Goodness of fit Index - AGFI as the development of the GFI index, is an index that has been adjusted to the ratio of the degree of freedom of the proposed model with the degree of freedom of the null model. The results show that the AGFI value is 0.871 , which is close to the recommended AGFI value $>0.9$, thus indicating that this model has a marginal fit. Tucker Lewis Index - TLI is an alternative to the incremental fit index that compares the tested model with the baseline. The recommended value as a good suitability level is $>0.90$. The results showed that the TLI value was 0.921 , so it could be stated that the level of conformity was at a good criterion. Comparative Fit Index - CFI, an incremental fit index that compares the tested model with the null model. The recommended value is CFI $\geq 0.90$. While the test results are 0.944, indicating that the model is good. The minimum Sample Discrepancy Function $\mathrm{CMIN} / \mathrm{DF}$ is a parsimonious suitability index that measures the goodness of fit model relationship and the estimated number 
of coefficients expected to achieve the level of conformity. The CMIN/DF result is 1.947 , which value is smaller than the recommended value $\mathrm{CMIN} / \mathrm{DF}<2.0$, indicating a good fit model.

The Root Mean Square Error of Approximation - RMSEA, an index used to compensate for Chi Square Statistics in a large sample. The RMSEA value indicates the expected goodnes of fit if the model is estimated in the population. The recommended acceptance value $\leq 0.08$, while the test results are 0.080 , indicating that the model is good. From the analysis of the suitability of the model it shows that if we look at AGFI, the path model used is quite good (Marginal). However, according to Imam (2013) states that there is a model that is not good, because it is looking for another fit model size. Other test results in terms of Chi square $(\mathrm{p}=0.411>0.05)$, GFI $(0.925>0.9)$ CMIN/DF $(1.947<2)$, RMSEA $(0.080 \leq 0.080)$, TLI $(0.921>0,9)$, and CFI $(0.944<0.90)$, show a good model. With reference to the opinion expressed by Imam $(2013)$, the path model proposed in this study has met the assumption of Goodness of Fit. Hypothesis testing with SEM analysis obtained the following path results:

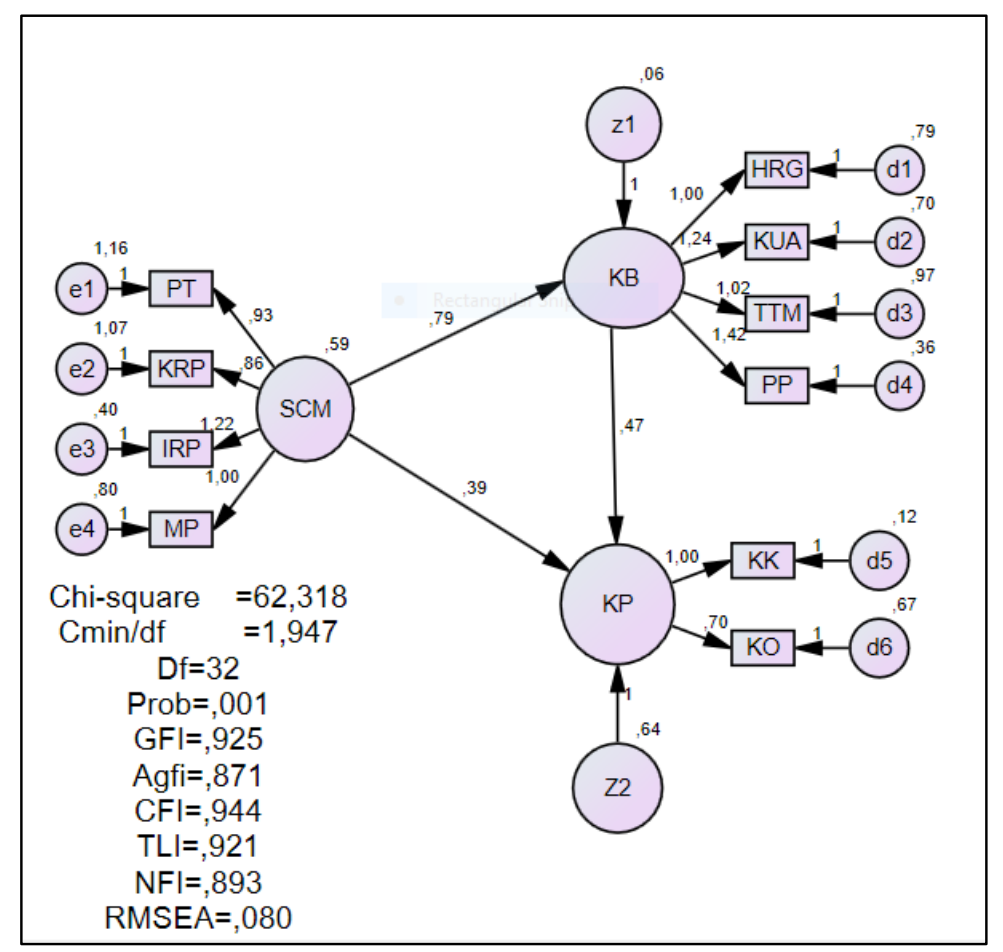

Fig. 1. Research Model

Table 3

Estimation of SEM Analysis Results

\begin{tabular}{llllll}
\multicolumn{2}{l}{ Relations Between Variables } & & Standardized Estimate & C.R. & P \\
\hline Competitive Advantage & $\leftarrow$ & SCM & 0.795 & 5.908 & 0.000 \\
Company Performance & $\leftarrow$ & SCM & 0.390 & 0.747 & 0.455 \\
Company performance & $\leftarrow$ & Competitive Advantage & 0.474 & 0.789 & 0.430 \\
\hline
\end{tabular}

Table 4

Direct, Indirect and Total Effects

\begin{tabular}{lllllll}
\hline & \multicolumn{2}{l}{ Direct Influence } & \multicolumn{2}{l}{ Indirect Influence } & \multicolumn{2}{l}{ Total Effect } \\
\hline & KB & KP & KB & KP & KB & KP \\
\hline SCM & 0.795 & 0.390 & - & 0.376 & 0.923 & 0.588 \\
\hline
\end{tabular}

In testing first hypothesis of that supply chain management has a positive effect on competitive advantage, the test results with Path analysis (SEM) can be seen that the weight of the standardized regression coefficient of supply chain management on competitive advantage is 0.795 with a $\mathrm{CR}$ value of 5.908 and a $\mathrm{p}$-value $(0.000<0.05)$. This means that supply chain management has a direct and significant positive effect on competitive advantage in Small and Medium Enterprises (SMEs) in West Java. 
Moreover, the results of the effect of competitive advantage on company performance showed that the weight of the standardized regression coefficient of competitive advantage on performance is 0.474 with a CR value of 0.789 and a $\mathrm{p}$ value $(0.0430<0.05)$. This means that competitive advantage has a significant positive effect on company performance in Small and Medium Enterprises (SMEs) in West Java.

The test results with Path analysis (SEM) of the hypothesis stating that Supply Chain Management has a positive effect on company performance showed that the weight of the standardized regression coefficient of supply chain management on company performance is 0.390 with a CR value of 0.747 and a $p$-value $(0.0430<0.05)$. This means that supply chain management has a direct and significant positive effect on company performance in Small and Medium Enterprises (SMEs) in West Java.

Based on the results of hypothesis testing of the effect of supply chain management on company performance through competitive advantage, the finding showed that that supply chain management has a significant positive effect on competitive advantage and competitive advantage has a significant effect on company performance. Thus, competitive advantage is a mediating variable in the relationship between supply chain management and company performance. While the magnitude of the indirect effect is 0.385 higher than the direct effect of supply chain management on performance, which is 0.379 . Thus, the competitive advantage is a good mediation of the relationship between supply chain management and performance. This means that when supply chain management is getting better, it will increase competitive advantage and ultimately will improve company performance.

\section{Conclusion}

The results of hypothesis testing indicate that all the hypotheses proposed in this study can be accepted. Supply chain management has a positive effect on company performance. This shows that the higher the level of application of supply chain management in a company, the better the company's performance. The results of this study also found that supply chain management has a positive effect on competitive advantage. This shows that the higher the level of implementation of supply chain management in a company, the company will be superior to other companies. The results of this study suggest that competitive advantage has a positive effect on company performance. This shows that the more superior a company is from other companies, the company's performance will increase as well. Furthermore, research finds that the influence of supply chain management on company performance is mediated by competitive advantage. In this study it was also found that the competitive advantage variable acts as a mediating variable.

\section{References}

Abor, J., \& Quartey, P. (2010). Issues in SME development in Ghana and South Africa. International Research Journal of Finance and Economics, 39(6), 215-228.

Agus, A. A., Isa, M., Farid, M. F., \& Permono, S. P. (2015). An assessment of SME competitiveness in Indonesia. Journal of Competitiveness, 7(2).

Alimohamadian, S., \& Abdi, F. (2014). Analyzing the effects of information technology on supply chain integration: The role of ERP success mediator. Management Science Letters, 4(4), 799-806.

Banerjee, M., \& Mishra, M. (2017). Retail supply chain management practices in India: A business intelligence perspective. Journal of Retailing and Consumer Services, 34, 248-259.

Bratić, D. (2011). Achieving a competitive advantage by SCM. IBIMA Business Review, 2011, 1-13.

Day, G. S., \& Wensley, R. (1988). Assessing advantage: a framework for diagnosing competitive superiority. Journal of marketing, 52(2), 1-20.

de Souza Miguel, P. L., \& Brito, L. A. L. (2011). Supply chain management measurement and its influence on operational performance. Journal of Operations and Supply Chain Management, 4(2), 56-70.

Fink, D. \& Disterer, G., (2006). International case studies: To what extent is ICT infused into the operations of SMEs?. Journal of Enterprise Information Management. Available: https://www.emerald.com/insight/content/doi/10.1108/17410390610708490/full/html

Green, K. W., Whitten, D., \& Inman, R. A. (2008). The impact of logistics performance on organizational performance in a supply chain context. Supply Chain Management: An International Journal, 13(4), 317-327.

Harrison, A., \& Van Hoek, R. I. (2008). Logistics management and strategy: competing through the supply chain. Pearson Education.

Heizer, J. \& Render, B., (2008). Principles of Operations Management, 7th Edition. Pearson Prentice Hall. New Jersey. Available: https://www.pearson.com/us/higher-education/program/Heizer-Principles-of-Operations-Management-7thEdition/PGM2813526.html

Henriksson, T., \& Nyberg, T. (2005). Supply chain management as a source of competitive advantage a case study of three fast-growth companies. rapport nr.: Ekonomistyrning.

Ilmiyati, A., \& Munawaroh, M. (2016). Pengaruh manajemen rantai pasokan terhadap keunggulan kompetitif dan kinerja perusahaan (Studi pada usaha kecil dan menengah di Kabupaten Bantul). Jurnal Manajemen Bisnis, 7(2), $226-251$.

Imam, G. (2013). Aplikasi Analisis Multivariate dengan Program IBM SPSS 21 Update PLS Regresi. Semarang. Badan Penerbit Universitas Diponegoro. ISBN, 979(015.1). 
Indrajit, R. E., \& Djokopranoto, R. (2002). Konsep Manajemen Supply Chain: Cara Baru Memendang Mata Rantai Penyediaan Barang.

Jamaludin, M., Fauzi, T. H., Nugraha, D. N. S., \& Adnani, L. (2020). Service Supply Chain Management in the Performance of National Logistics Agency in National Food Security. International Journal of Supply Chain Management, 9(3), 1080.

Jamaludin, M., Fauzi, T., \& Nugraha, D. (2021). A system dynamics approach for analyzing supply chain industry: Evidence from rice industry. Uncertain Supply Chain Management, 9(1), 217-226.

Koh, S. L., Demirbag, M., Bayraktar, E., Tatoglu, E., \& Zaim, S. (2007). The impact of supply chain management practices on performance of SMEs. Industrial Management \& Data Systems, 107(1).

Kuncoro, M. (2006). Strategi bagaimana meraih keunggulan kompetitif.

Kushwaha, G. S. (2011). Competitive advantage through information and communication technology (ICT) enabled supply chain management practices. International Journal of Enterprise Computing and Business Systems, 1(2), 1-13.

Larson, P. D. (2001). Designing and managing the supply chain: concepts, strategies, and case studies. Journal of Business Logistics, 22(1), 259.

Lee, K. L. (2015). Relationship of supply chain capabilities and supply chain technology adoption towards supply chain operational performance in textile and apparel industry (Doctoral dissertation, Universiti Utara Malaysia).

Li, S., Ragu-Nathan, B., Ragu-Nathan, T. S., \& Rao, S. S. (2006). The impact of supply chain management practices on competitive advantage and organizational performance. Omega, 34(2), 107-124.

Lin, C. Y., \& Ho, Y. H. (2007). Technological innovation for China's logistics industry.

Obeidat, B. Y. (2016). Exploring the relationship between corporate social responsibility, employee engagement, and organizational performance: The case of Jordanian mobile telecommunication companies. International Journal of Communications, Network and System Sciences, 9(09), 361.

Porter, M. E. (1985). Competitive strategy: Creating and sustaining superior performance. The free, New York.

Prakosa, B., \& Imam, G. (2005). Effect of Market Orientation, Innovation and Learning Orientation on Company Performance to Achieve Competitive Advantages (Empirical Studies in Manufacturing Industry in Semarang). Journal of Management and Organizational Studies, 2(1), 8-27.

Rahmasari, L. (2011). Pengaruh supply chain management terhadap kinerja perusahaan dan keunggulan bersaing (Studi kasus pada industri kreatif di Provinsi Jawa Tengah). Majalah Ilmiah Informatika, 2(3).

Siagian, Y. M. (2005). Aplikasi Supply Chain Management dalam Dunia Bisnis. Grasindo. Jakarta.

Simchi-Levi, D., Kaminsky, P., Simchi-Levi, E., \& Shankar, R. (2008). Designing and managing the supply chain: concepts, strategies and case studies. Tata McGraw-Hill Education.

Tambunan, T. (2008). Development of SME in ASEAN with Reference to Indonesia and Thailand. Southeast Asian Journal of Economics, 20(1), 53-83.

Tan, K. C. (2001). A framework of supply chain management literature. European Journal of Purchasing \& Supply Management, 7(1), 39-48.

Thakkar, J., Kanda, A., \& Deshmukh, S. G. (2008). Supply chain management in SMEs: development of constructs and propositions. Asia Pacific Journal of Marketing and Logistics, 20(1).

Turban, E., Volonino, L., Wood, G. R., \& Sipior, J. C. (2013). Profitable Business Growth. inInformation Technology for Management: Advancing Sustainable, Wiley.

Ubud, S. (2013). Peningkatan Keunggulan Bersaing melalui Supply Chain Flexibility beserta Variabel Antecentnta pada Industri Manufaktur di Jawa Timur. Jurnal Aplikasi Manajemen, 7(3).

Wu, L., Chuang, C. H., \& Hsu, C. H. (2014). Information sharing and collaborative behaviors in enabling supply chain performance: A social exchange perspective. International Journal of Production Economics, 148, 122-132.

Wulandari, W., Sari, R. N., \& Al Azhar, L. (2017). Pengaruh Supply Chain Management Terhadap Kinerja Perusahaan Melalui Keunggulan Bersaing. Jurnal Ekonomi, 21(3), 462-479.

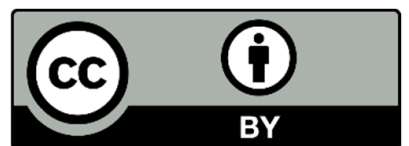

(C) 2021 by the authors; licensee Growing Science, Canada. This is an open access article distributed under the terms and conditions of the Creative Commons Attribution (CC-BY) license (http://creativecommons.org/licenses/by/4.0/). 